\title{
INTERACTIONS BETWEEN GILLNET FISHERIES AND SMALL CETACEANS IN NORTHERN RIO DE JANEIRO, BRAZIL: 2001-2002
}

\author{
Ana Paula Madeira Di Beneditto ${ }^{1}$
}

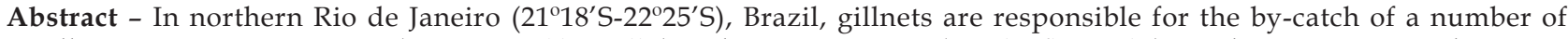
small cetaceans. Franciscanas (Pontoporia blainvillei) and marine tucuxis (Sotalia fluviatilis) are the most impacted species. From November 2001 to October 2002 data on fisheries and mortality of small cetaceans were obtained through interviews with fishermen of $20 \%$ of the gillnet fleet. Seasons were grouped into spring-summer and autumn-winter and the region was divided into two fishing areas: Area I (Barra do Itabapoana to São Tomé Cape) and Area II (São Tomé Cape to Macaé). A total of 374 gillnet operations were recorded between 0.02-42.1n.miles from shore and in waters $5-67 \mathrm{~m}$ deep. Gillnets were $3.1 \mathrm{~m}$ in length and of $120 \mathrm{~mm}$ mesh size. The fishing effort for the entire fleet $(\mathrm{n}=50$ boats) was estimated at $7,161.8 \mathrm{~km}$ of net and the total number of small cetaceans caught was 225 . The CPUE was 0.031 animal $\times(\mathrm{km}$ of net $\times$ day $)^{-1}$. Fisheries and by-catches did not show seasonal differences. Fishing trips were more prevalent in Area I, whereas the by-catch of franciscanas and marine tucuxis was higher in Area II. Fisheries were distributed uniformly in areas close to shore (first 10n.miles) and beyond. In Area I they occurred predominantly within the 30-m isobath. The by-catch of franciscanas and marine tucuxis also occurred within these limits, suggesting that $30-\mathrm{m}$ isobath may constitute the offshore limit of their distribution along the coast. The variability in the width of the continental shelf in Areas I and II may explain the differences in the magnitude of the by-catch of small cetaceans in these areas. Gillnet fisheries may adversely impact the coastal populations of small cetaceans. In northern Rio de Janeiro, particularly between $22^{\circ} 00^{\prime} S$ and $22^{\circ} 25^{\prime} \mathrm{S}$ where the $30-\mathrm{m}$ isobath is found close to shore, fisheries operating within the first $10 \mathrm{n}$.miles from shore can pose substantial threat to dolphins. Due to the distribution of their preferred prey, franciscanas may be at greater risk of by-catch in areas near the Paraíba do Sul river mouth. It is thus proposed that these areas be closed to gillnet fisheries year round, so that the impact on coastal dolphins is minimised.
\end{abstract}

Resumo - No norte do Rio de Janeiro $\left(21^{\circ} 18 S^{\prime}-22^{\circ} 25^{\prime} S\right)$, Brasil, redes de espera são responsáveis pela captura acidental de vários pequenos cetáceos. Franciscanas (Pontoporia blainvillei) e tucuxis marinhos (Sotalia fluviatilis) são as espécies mais impactadas. Entre novembro de 2001 a outubro de 2002 dados sobre pescarias e mortalidade de pequenos cetáceos foram obtidos através de entrevistas com pescadores de $20 \%$ da frota pesqueira de rede de espera. As estações do ano foram agrupadas em primavera-verão e outono-inverno e a região foi dividida em duas áreas de pesca: área I (Barra do Itabapoana ao Cabo de São Tomé) e área II (Cabo de São Tomé a Macaé). Ao todo, 374 operações com rede de espera foram registradas entre 0,02-42,1 milhas da costa e $5-67 \mathrm{~m}$ de profundidade. As redes de espera tinham $3,1 \mathrm{~km}$ de comprimento e $120 \mathrm{~mm}$ de tamanho de malha. O esforço de pesca para toda frota $(\mathrm{n}=50$ barcos) foi estimado em $7.161,8 \mathrm{~km}$ de rede e o número total de pequenos cetáceos capturados foi de 225 . A CPUE foi de 0,031 animal $\times(\mathrm{km} \text { of rede } \times \text { dia })^{-1}$. Pescarias e capturas acidentais não apresentaram diferenças sazonais. Operações de pesca prevaleceram na área I, enquanto a captura de franciscanas e tucuxis marinhos foi mais alta na área II. Pescarias se distribuíram uniformemente em áreas próximas da costa (primeiras 10 milhas náuticas) e além desse limite. Na área I elas ocorreram predominantemente até a isóbata de $30 \mathrm{~m}$. A captura de franciscanas e tucuxis marinhos também ocorreu dentro desses limites, sugerindo que a isóbata de $30 \mathrm{~m}$ pode representar o limite de sua distribuição ao longo da costa. A variação na largura da plataforma continental entre as áreas I e II pode explicar as diferenças na magnitude da captura de pequenos cetáceos. Pescarias com rede de espera podem afetar adversamente as populações costeiras de pequenos cetáceos. No norte do Rio de Janeiro, particularmente entre $22^{\circ} 00^{\prime} \mathrm{S}$ e $22^{\circ} 25^{\prime} \mathrm{S}$ onde a isóbata de $30 \mathrm{~m}$ está localizada próximo da costa, operações pesqueiras nas primeiras 10 milhas náuticas de distância da costa podem causar ameaça substancial aos golfinhos. Devido a distribuição de suas presas preferenciais, as franciscanas podem apresentar maior risco de captura em áreas próximas da foz do rio Paraíba do Sul. Dessa forma, propõe-se que as pescarias com rede de espera sejam proibidas nessas áreas durante todo o ano, a fim de minimizar o impacto sobre os golfinhos costeiros.

Keywords: gillnet fishery, small cetaceans, by-catch, Pontoporia blainvillei, Sotalia fluviatilis, southeastern Brazil.

\section{Introduction}

In northern Rio de Janeiro State, southeastern Brazil, passive gillnets are the only fishing gear known to incidentally catch small cetaceans. Seven species have already been recorded: franciscana (Pontoporia blainvillei), marine tucuxi (Sotalia fluviatilis), bottlenose dolphin (Tursiops truncatus), Atlantic spotted dolphin (Stenella frontalis), rough-toothed dolphin (Steno bredanensis), long-beaked common dolphin (Delphinus capensis) and false killer whale (Pseudorca crassidens) (Lodi and Capistrano, 1990; Di Beneditto et al., 1998; Di Beneditto, 2001).
Among these cetaceans the former two species represent about $95 \%$ of the records and the by-catch is restricted to the first 10 n.miles from shore, or the $30 \mathrm{~m}$ isobath (Di Beneditto et al., 2001a). Due to their mostly inshore distribution, franciscana and marine tucuxi are more vulnerable to coastal fishing operations. This trend has also been for other areas where these two species occur (Corcuera et al., 1994; Siciliano, 1994; Secchi et al., 1997; Monteiro-Neto et al., 2000; Ott et al., 2002).

The main purpose of this paper is to describe the gillnet fisheries in northern Rio de Janeiro and quantify their interactions with small cetaceans, particularly the franciscana and the marine tucuxi. 


\section{Material and Methods}

This study took place in the northern coast of Rio de Janeiro, Brazil. The boundaries of the study area were Barra do Itabapoana $\left(21^{\circ} 18^{\prime} S\right)$ to the north, and Macaé $\left(22^{\circ} 25^{\prime} S\right)$ to the south, as well as the continental shelf break along the $100 \mathrm{~m}$-isobath. The two major river runoffs of Rio de Janeiro (Itabapoana and Paraíba do Sul rivers) are located in this area (Muehe and Valentini, 1998). The village of Atafona ( $21^{\circ} 37^{\prime}$ S $)$ encompasses the most representative harbour in terms of gillnets fishing effort, from which around 50 boats operate (Di Beneditto et al., 2001a) (Figure 1).

From November 2001 to October 2002, gillnet fisheries were monitored through weekly interviews with the skipper of 10 boats based in Atafona, corresponding to $20 \%$ of the gillnet fleet. Boat selection was done randomly each week, with no particular boat being continuously monitored during the entire period. Information requested from the fishermen included: (1) gillnet dimensions, (2) days of fishing operations, (3) gillnet position at sea (fishing area, distance from shore and depth), and (4) small cetacean mortality data. The unit effort was expressed as linear kilometres of net immersed per day of fishing operations. Total fishing effort was based on the data obtained weekly. Catch per unit effort (CPUE) of small cetaceans was expressed as the number of animals captured per linear kilometre of net $x$ day. The cetacean species were identified through full carcasses or any remains (e.g. head or fins) brought to shore by fishermen.

In order to analyse the seasonality of gillnet fishing operations and of the by-catch data, seasons were grouped into spring-summer (October to March) and autumn-winter (April to September). These seasons include the highest and lowest recorded values of temperature and rainfall, respectively (Martin et al., 1998; Muehe and Valentini, 1998).

The northern Rio de Janeiro coast was divided into two fishing areas: Area I, from Barra do Itabapoana to São Tomé Cape $\left(22^{\circ} 00^{\prime} S\right)$, and Area II, from São Tomé Cape to Macaé. Area I is strongly influenced by Itabapoana and Paraíba do Sul rivers runoffs, while in Area II the effects of the Central Water of South Atlantic (CWSA) up-welling are present, specially during spring-summer months (Valentin and Monteiro-Ribas, 1993; Muehe and Valentini, 1998). According to the Nautical Charts $\mathrm{n}^{\circ}$ 1.403 and 1.500 from the Hydrograph and Navigation Department/Brazilian Navy, the 30m-isobath is located around 30-35 n.miles from the coastline in Area I, while the same isobath is situated about 7-14n.miles from shore in Area II (Figure 1).

Differences among seasonality, fishing grounds and small cetaceans by-catch proportions were tested by a normal approximation of the chi-square test (Zar, 1996), using Statistica for Windows vs. 5.5 program procedures.

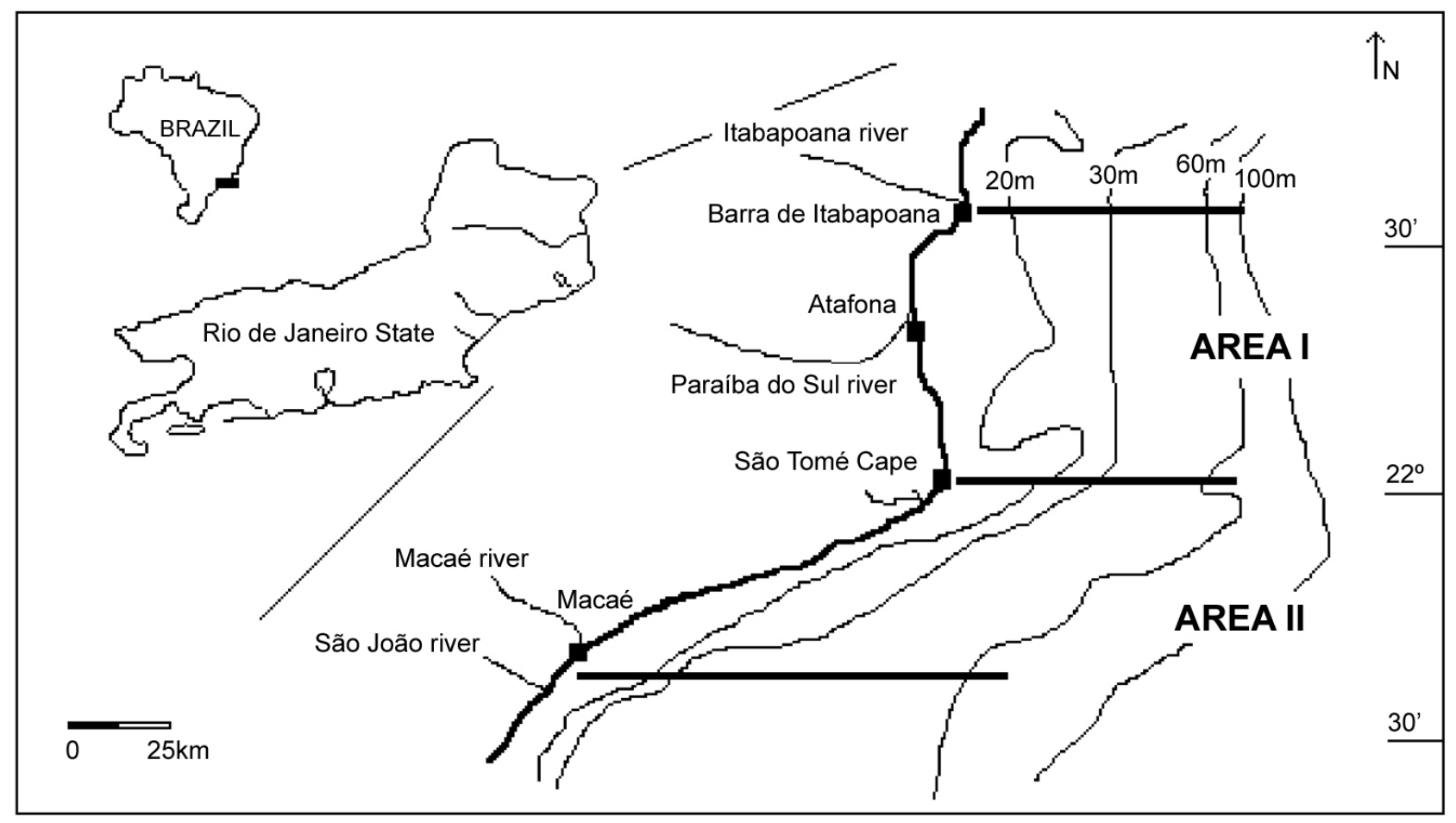

Figura 1. Map of Rio de Janeiro State with the geographis limits of the northern coast, the major rivers runoffs, the village of Atafona, the São Tomé Cape, the bathymetric characteristics and the fishing grounds (Area I and II). 


\section{Results}

During the study period 374 gillnet operations were recorded. Passive gillnets were made of monofilament and varied from $1.3-4.9 \mathrm{~km}$ in length $($ mean $=3.1 ; \mathrm{SD}=$ $0.6) ; 1.9-6.0 \mathrm{~m}$ in height (mean $=4.2$; $\mathrm{SD}=1.2)$; and 100 $300 \mathrm{~mm}$ stretched size mesh $($ mean $=120 ; \mathrm{SD}=10)$. The fishing boats were $10-12 \mathrm{~m}$ in length and had load capacity of approximately 2-4 tons.

Fishing trips took place 2-4 weeks per month, or 2-6 days a week. The nets were deployed at sea 1-8 times each week, with soaking time being about 12 hours in each net setting. Poor weather conditions (e.g. strong winds), present in all seasons, accounted for the variability in the local fisheries data. These conditions constrained the fisheries during a few weeks/year or forced the boats to return earlier to the harbour. Throughout the entire fishing ground $\left(21^{\circ} 18^{\prime} \mathrm{S}-22^{\circ} 25^{\prime} \mathrm{S}\right)$, the gillnet operations were conducted from 0.02 to $42.1 \mathrm{n}$. miles from shore $($ mean $=15.2 ; \mathrm{SD}=12.1$ ) and from 5 to $67 \mathrm{~m}$ of depth (mean $=26.8 ; \mathrm{SD}=15.9)$.

Fishing effort for all monitored boats was $1,432.4 \mathrm{~km}$ per year, with an average of $119.4 \mathrm{~km}$ per month $(\mathrm{SD}=$ 31.2). Extrapolating it to the entire fleet, the effort was about $7,161.8 \mathrm{~km}$ per year, with an average of $596.8 \mathrm{~km}$ per month $(S D=155.8)$. Figure 2 represents the monthly effort along the studied period.

Forty-five small cetacean species were recorded: franciscana (22), marine tucuxi (20), Atlantic spotted dolphin (2) and one (1) unidentified dolphin (Table 1). Assuming a constant probability of by-catch to the entire gillnet fleet, the yearly number of small cetaceans caught in gillnets was 225: 110 franciscanas, 100 marine tucuxis, 10 Atlantic spotted dolphins and 5 unidentified dolphins. The CPUE estimate was about 0.031 animal $\times(\mathrm{km}$ of net $\times$ day $)^{-1}$; franciscana and marine tucuxi values were 0.015 and 0.014 , respectively.
Gillnet fisheries, as well as the by-catch of franciscana and marine tucuxi, did not show significant differences between the seasons of spring-summer and autumnwinter $(p>0.05)$. Gillnet fisheries were more prevalent in Area I than in Area II $(p=0.0000)$, while the by-catches were more prevalent in Area II for the franciscana ( $p=$ $0.0000)$ and the marine tucuxi $(p=0.0002)$. The number of fishing trips in all fishing ground was similar in the first 10n.miles from shore $(47.6 \%)$ and beyond this limit $(52.4 \%)(p=0.1897)$. On the other hand, in Area I the fisheries occurred mainly in waters $\leq 30$ m deep $(81.9 \%)$ $(p=0.0000)$. The by-catch of franciscana occurred mainly within the first 10n.miles from shore $(100 \%)$ and in waters $\leq 30 \mathrm{~m}$ deep $(95.5 \%)$. A similar pattern was recorded for the marine tucuxi, with $85 \%$ of the captures occurring up to 10 n.miles from shore and $100 \%$ of them in waters $\leq 30 \mathrm{~m}$ deep (Table 2 ).

\section{Discussion}

In northern Rio de Janeiro the gillnet fisheries are carried out all year round and these fisheries extend to 40n.miles from shore and into waters $60 \mathrm{~m}$ deep, as recorded in this and other studies (Lodi and Capistrano, 1990; Di Beneditto, 2001). We have, however, detected changes in net dimensions through time. According to the above authors, from 1987 to 1999 the most commonly-used gillnet measured $2.3 \mathrm{~km}$ in length and $140 \mathrm{~mm}$ in stretched-mesh size. These values are 35\% shorter and 15\% larger than the present length and mesh size, respectively. Smaller mesh size generally result in a catch of predominantly immature specimens of the same target species (Garcia-Mellado et al., 2002; Carlson and Cortés, 2003). Consequently, this mesh size change could cause an overexploitation of the target species (Norse, 1993). Gillnet dimensions currently in use in northern Rio de Janeiro could result in a gradual collapse in the local fishing activity.

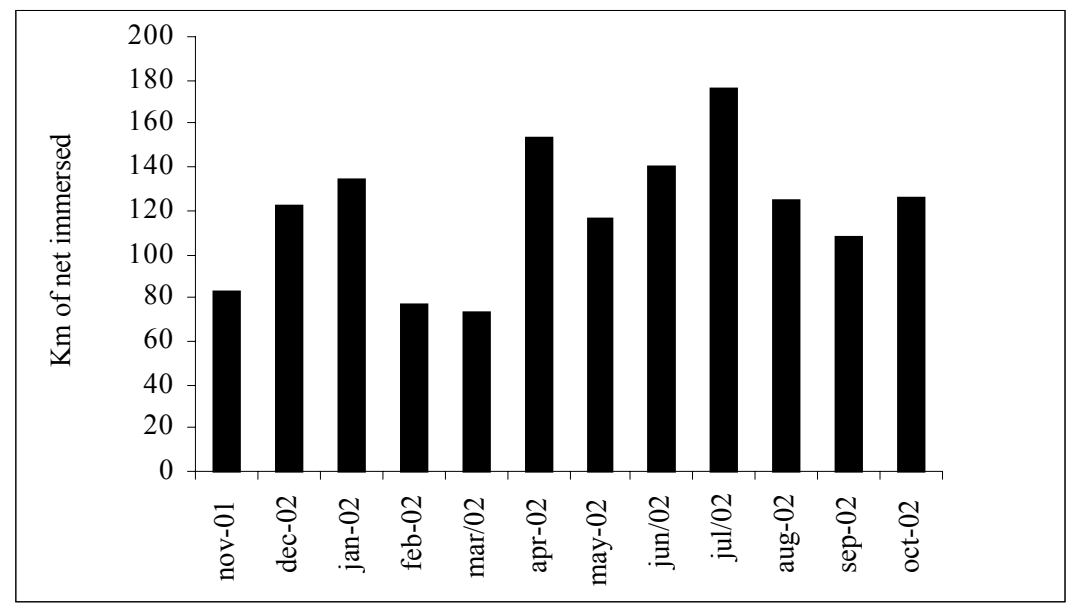

Figure 2. Monthly fishing effort of $20 \%$ of the gillnet fleet ( $n=10$ boats) based at the village of Atafona, northern Rio de Janeiro State, from November 2001 to October 2002. 
Table 1. Characteristics of the by-catch of small cetaceans in northern Rio de Janeiro State, Brazil: 2001-2002.

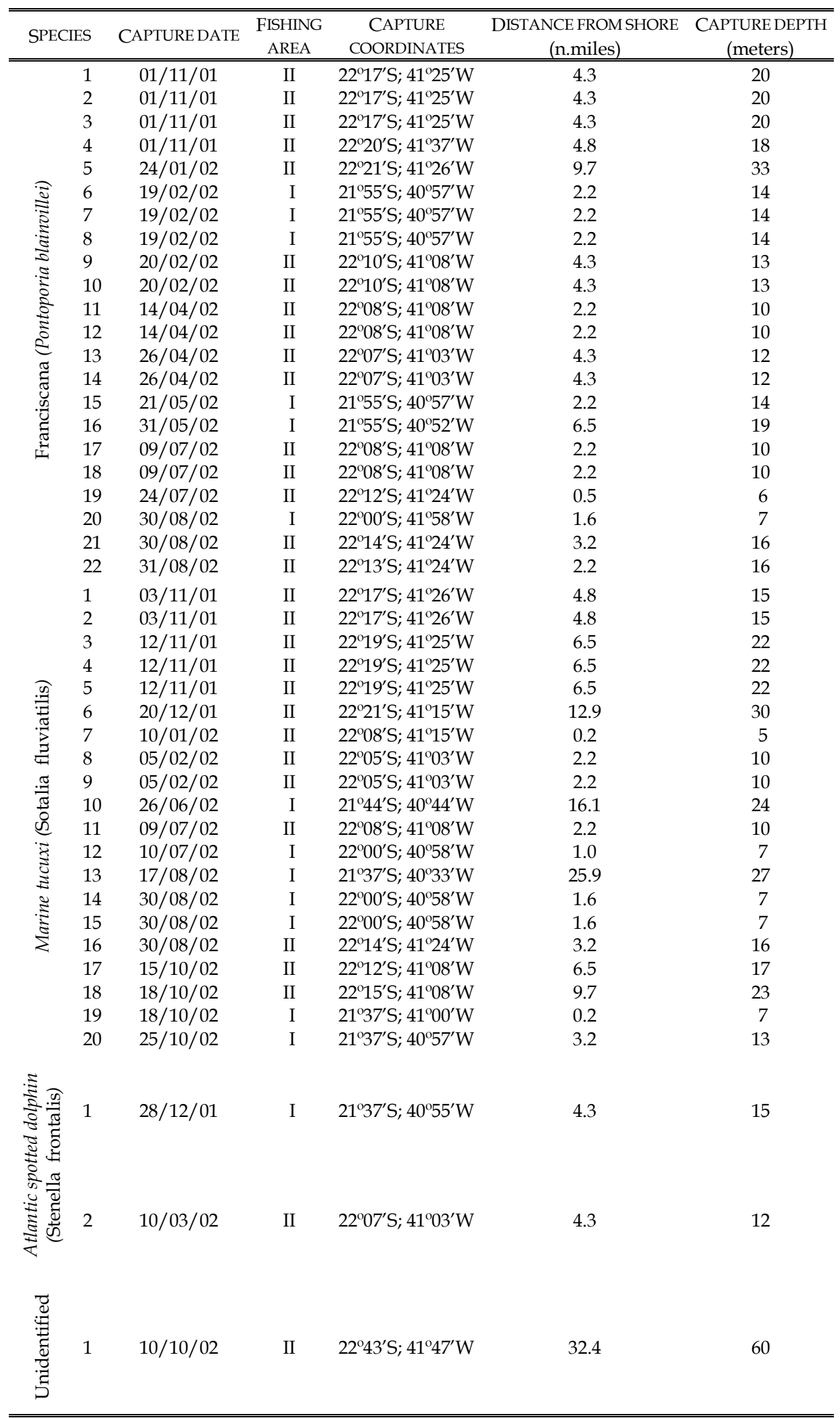


Table 2. Comparisons among seasonality, fishing grounds (areas, coastline distance and depth) and small cetaceans by-catch proportions in northern Rio de Janeiro, by a normal approximation of the chi-square test.

\begin{tabular}{|c|c|c|c|c|c|c|c|c|}
\hline PARAMETERS & \multicolumn{2}{|c|}{ SEASONALITY } & \multicolumn{2}{|c|}{ FISHING AREA } & \multicolumn{2}{|c|}{ DISTANCE FROM SHORE } & \multicolumn{2}{|c|}{ DEPTH } \\
\hline \multirow{4}{*}{$\begin{array}{l}\text { Gillnet fisheries } \\
(374=100 \%)\end{array}$} & $\begin{array}{l}\text { Spring- } \\
\text { summer }\end{array}$ & $\begin{array}{l}\text { Autumn- } \\
\text { winter }\end{array}$ & Area I & Area II & $\begin{array}{l}\text { First } 10 \mathrm{n} . \\
\text { miles }\end{array}$ & $\begin{array}{l}\text { Beyond } 10 \\
\text { n. miles }\end{array}$ & $\begin{array}{c}\text { Until } 30 \mathrm{~m} \\
\text { of } \\
\text { depth }\end{array}$ & $\begin{array}{c}\text { Beyond } \\
30 \mathrm{~m} \text { of } \\
\text { depth }\end{array}$ \\
\hline & $N=167$ & $\mathrm{~N}=207$ & $N=259$ & $N=115$ & $\mathrm{~N}=178$ & $\mathrm{~N}=196$ & $\mathrm{~N}=277$ & $\mathrm{~N}=97$ \\
\hline & $44.7 \%$ & $55.3 \%$ & $69.3 \%$ & $30.7 \%$ & $47.6 \%$ & $52.4 \%$ & $74.1 \%$ & $25.9 \%$ \\
\hline & \multicolumn{2}{|c|}{$p=0.0559$} & \multicolumn{2}{|c|}{$p=0.0000$ * } & \multicolumn{2}{|c|}{$p=0.1897$} & \multicolumn{2}{|c|}{$p=0.0000^{*}$} \\
\hline \multirow{3}{*}{$\begin{array}{l}\text { Fisheries - Area I } \\
(259=100 \%)\end{array}$} & $\mathrm{N}=115$ & $\mathrm{~N}=144$ & & & $\mathrm{~N}=115$ & $\mathrm{~N}=144$ & $\mathrm{~N}=212$ & $\mathrm{~N}=47$ \\
\hline & $44.4 \%$ & $55.6 \%$ & & & $44.4 \%$ & $55.6 \%$ & $81.9 \%$ & $18.1 \%$ \\
\hline & \multicolumn{2}{|c|}{$p=0.1117$} & & & \multicolumn{2}{|c|}{$p=0.1117$} & \multicolumn{2}{|c|}{$p=0.0000$ * } \\
\hline \multirow{3}{*}{$\begin{array}{l}\text { Fisheries - Area II } \\
(115=100 \%)\end{array}$} & $\mathrm{N}=53$ & $\mathrm{~N}=62$ & & & $N=63$ & $\mathrm{~N}=52$ & $N=65$ & $\mathrm{~N}=50$ \\
\hline & $46.1 \%$ & $53.9 \%$ & & & $54.8 \%$ & $45.2 \%$ & $56.5 \%$ & $43.5 \%$ \\
\hline & \multicolumn{2}{|c|}{$p=0.2263$} & & & \multicolumn{2}{|c|}{$p=0.1308$} & \multicolumn{2}{|c|}{$p=0.0701$} \\
\hline \multirow{4}{*}{$\begin{array}{l}\text { Franciscana } \\
\text { by-catch }\end{array}$} & $\begin{array}{l}N=167 \\
(100 \%)\end{array}$ & $\begin{array}{l}N=207 \\
(100 \%)\end{array}$ & $\begin{array}{l}N=259 \\
(100 \%)\end{array}$ & $\begin{array}{l}N=115 \\
(100 \%)\end{array}$ & $\begin{array}{l}N=178 \\
(100 \%)\end{array}$ & $\begin{array}{l}N=196 \\
(100 \%)\end{array}$ & $\begin{array}{l}N=277 \\
(100 \%)\end{array}$ & $\begin{array}{l}N=97 \\
(100 \%)\end{array}$ \\
\hline & $\begin{array}{c}\mathrm{N}=10 \\
\text { animals }\end{array}$ & $\begin{array}{c}\mathrm{N}=12 \\
\text { animals }\end{array}$ & $\begin{array}{c}\mathrm{N}=6 \\
\text { animals }\end{array}$ & $\begin{array}{c}\mathrm{N}=16 \\
\text { animals }\end{array}$ & $\begin{array}{c}\mathrm{N}=22 \\
\text { animals }\end{array}$ & $\mathrm{N}=0$ & $\begin{array}{c}\mathrm{N}=21 \\
\text { animals }\end{array}$ & $\mathrm{N}=1$ animal \\
\hline & $6.0 \%$ & $5.8 \%$ & $2.3 \%$ & $13.9 \%$ & $12.4 \%$ & $0.0 \%$ & $7.6 \%$ & $1.0 \%$ \\
\hline & \multicolumn{2}{|c|}{$p=0.9349$} & \multicolumn{2}{|c|}{$p=0.0000$ * } & \multicolumn{2}{|c|}{$p=0.0000$ * } & \multicolumn{2}{|c|}{$p=0.0142$ * } \\
\hline \multirow{4}{*}{$\begin{array}{l}\text { Marine tucuxi } \\
\text { by-catch }\end{array}$} & $\begin{array}{l}N=167 \\
(100 \%)\end{array}$ & $\begin{array}{l}N=207 \\
(100 \%)\end{array}$ & $\begin{array}{l}N=259 \\
(100 \%)\end{array}$ & $\begin{array}{l}N=115 \\
(100 \%)\end{array}$ & $\begin{array}{l}N=178 \\
(100 \%)\end{array}$ & $\begin{array}{l}N=196 \\
(100 \%)\end{array}$ & $\begin{array}{l}N=277 \\
(100 \%)\end{array}$ & $\begin{array}{l}N=97 \\
(100 \%)\end{array}$ \\
\hline & $\begin{array}{c}\mathrm{N}=13 \\
\text { animals }\end{array}$ & $\begin{array}{c}\mathrm{N}=7 \\
\text { animals }\end{array}$ & $\begin{array}{c}\mathrm{N}=7 \\
\text { animals }\end{array}$ & $\begin{array}{c}\mathrm{N}=13 \\
\text { animals }\end{array}$ & $\begin{array}{c}\mathrm{N}=17 \\
\text { animals }\end{array}$ & $\begin{array}{c}\mathrm{N}=3 \\
\text { animals }\end{array}$ & $\begin{array}{c}\mathrm{N}=20 \\
\text { animals }\end{array}$ & $N=0$ \\
\hline & $7.8 \%$ & $3.4 \%$ & $2.7 \%$ & $11.3 \%$ & $9.6 \%$ & $1.5 \%$ & $7.2 \%$ & $0.0 \%$ \\
\hline & \multicolumn{2}{|c|}{$p=0.0612$} & \multicolumn{2}{|c|}{$p=0.0002$ * } & \multicolumn{2}{|c|}{$p=0.0006^{*}$} & \multicolumn{2}{|c|}{$p=0.0078^{*}$} \\
\hline
\end{tabular}

* Significant differences.

About $69 \%$ of the gillnet operations are concentrated in Area I. We propose the following non-excluding factors to explain these disproportionate figures it: i) fishing areas are close to the Atafona harbour, where the boats are based, ii) boats avoid south São Tomé Cape region due to the intensive traffic of cargo vessels which can cause serious damage to their nets, and iii) the continental shelf is narrower in Area I and fishermen may prefer fishing in these waters.

Data on gillnet fishery in northern Rio de Janeiro from 1987-96 (Di Beneditto et al., 1998) indicate that, during that period, approximately 60 boats used gillnets and the total effort each year was around $12,000 \mathrm{~km}$ of net. Since then, the number of gillnet boats has decreased to 50 and fishing effort each year (during 1997-99) was 9,700km of net (Di Beneditto and Ramos, 2001). Despite our data extrapolation to the fleet at-large, the fishing effort we report in this study (about 7,200 km of net) was obtained through systematic boat monitoring, and accounted for the variability in the fishing effort throughout the year due to poor weather conditions. This approach was not taken in the previous studies (Di Beneditto et al., 1998; Di Beneditto and Ramos, 2001), as all boats were assumed to operate during 5 days/week and 4 weeks/month. As such, those values could have overestimated the local gillnet fishing effort (Table 3).

From 1987 to 1999 , the annual number of small cetaceans by-caught in northern Rio de Janeiro ranged from 10 to 85, including all species (Di Beneditto, unpublished data). In the present study, the number recorded was 225, a figure substantially higher than the ones estimated for the previous years (Table 3 ). This large discrepancy may reflect biases in the sampling procedures during that time. The continuation of the gillnet fleet monitoring using the method standardised in the present study should be done in order to confirm the actual trend in the by-catch of small cetaceans in this region.

Nevertheless, the magnitude of the by-catch estimated here warrants concern, despite the lack of abundance estimates for the two main species involved. In the case of franciscana, there is evidence that the population in northern Rio de Janeiro might be more vulnerable than the population from southern Brazil, as the former shows relatively lower genetic variability (Secchi et al., 1998). 
Table 3. Annual fishing effort and by-catch of small cetaceans in northern Rio de Janeiro, Brazil, during 1987-96, 1997-99 and 2001-02.

\begin{tabular}{cccc}
\hline \hline & & ANNUAL FISHING EFFORT \\
PERIOD & $(\mathrm{km})$ & $\begin{array}{c}\text { NUMBER OF SMALL CETACEANSBY-CATCH } \\
\text { RANGE }\end{array}$ & $\begin{array}{c}\text { SMALL CETACEANS CPUE } \\
\text { RANGE }\end{array}$ \\
& & AVERAGE \pm SD & $0.001-0.007^{4}$ \\
$1987-96$ & $12,000^{1}$ & $16-85^{4}$ & $0.004 \pm 0.002$ \\
& & $50.8 \pm 22.7$ & $0.001-0.0044^{4}$ \\
$1997-99$ & $9,700^{2}$ & $10-38^{4}$ & $0.003 \pm 0.002$ \\
$2001-02$ & $7,200^{3}$ & $24.3 \pm 14.0$ & 0.031 \\
\hline \hline
\end{tabular}

(1) Di Beneditto et al. (1998); (2) Di Beneditto and Ramos (2001); (3) present study; (4) Di Beneditto, unpublished data.

Among the small cetacean species, by-catches of franciscana and marine tucuxi were the more representative. The strong correlation between the operation of coastal fisheries and the by-catch of small cetaceans has been reported elsewhere in the western South Atlantic (Praderi et al., 1989; Corcuera, 1994; Siciliano, 1994; Secchi et al., 1997). There are no CPUE estimates for marine tucuxi outside of northern Rio de Janeiro. On the other hand, CPUE of franciscana has been calculated for several areas (e.g. southern Brazil: Secchi et al. (1997) and Ott (1998); Uruguay: Praderi (1997) and Argentina: Perez-Macri and Crespo (1989) and Corcuera et al. (1994)). Recently, Ott et al. (2002) compiled information about interactions between the franciscana and fisheries throughout its range; Table 4 shows the comparison between their data and the present study. The CPUE value in northern Rio de Janeiro from 2001-02 was lower than those reported for southern Brazil $\left(\sim 29^{\circ}-32^{\circ} \mathrm{S}\right)$ and Argentina $\left(\sim 35^{\circ}-40^{\circ} \mathrm{S}\right)$, a possible reflection of differences in the franciscana population size, dynamics of the gillnet fleets, gillnet dimensions and their operational characteristics, differences in sampling procedures or a combination of these factors. The lack of seasonality and the predominance of small cetacean by-catch in Area II were already noted for northern Rio de Janeiro (Lodi and Capistrano, 1990; Di Beneditto, 1997). According to the by-catch data, the $30-\mathrm{m}$ isobath is the offshore limit of the franciscana and the marine tucuxi. Using the Nautical Charts $\mathrm{n}^{\circ} 1.403$ and 1.500 from the Brazilian Navy, the potential distribution range of both species within $30-\mathrm{m}$ isobath limit is around $3,960 \mathrm{~km}^{2}$ in the entire fishing ground, being $2,400 \mathrm{~km}^{2}$ in Area I (60.6\%) and $1,560 \mathrm{~km}^{2}$ in Area II (39.4\%). Although the gillnet effort was greater in Area I, the by-catch of small cetaceans was than that of Area II. Assuming that 30-m isobath defines the inshore distribution of these species, the differences in width of the continental shelf at those depths may influence the magnitude of the by-catch of small cetaceans in this area.

Table 4. Comparisons of CPUE data of franciscanas (Pontoporia blainvillei) in several areas of their distribution.

\begin{tabular}{lc}
\hline \hline Locality & CPUE \\
\hline $\begin{array}{l}\text { Northern Rio de Janeiro State, Brazil } \\
\left(21^{\circ} 18^{\prime} \mathrm{S}-22^{\circ} 25^{\prime} \mathrm{S}\right)\end{array}$ & 0.0002 to $0.002^{1}$ \\
$1987-99$ & $0.015^{2}$ \\
$2001-02$ & \\
Northern São Paulo State, Brazil & $0.002^{3}$ \\
$\left(23^{\circ} 59^{\prime} \mathrm{S}-24^{\circ} 20^{\prime} \mathrm{S}\right)$ & \\
Northern Rio Grande do Sul State, Brazil & 0.054 to $0.088^{3}$ \\
$\left(29^{\circ} 15^{\prime} \mathrm{S}-29^{\circ} 58^{\prime} \mathrm{S}\right)$ & \\
Southern Rio Grande do Sul State, Brazil & $0.010^{3}$ \\
$\left(32^{\circ} 05^{\prime} \mathrm{S}\right)$ & \\
Uruguay & $0.0064^{3}$ \\
$\left(33^{\circ} 45^{\prime} \mathrm{S}-34^{\circ} 35^{\prime} \mathrm{S}\right)$ & \\
North Buenos Aires Province, Argentina & \\
$\left(35^{\circ} 00^{\prime} \mathrm{S}-38^{\circ} 08^{\prime} \mathrm{S}\right)$ & 0.2161 to $0.4289^{3}$ \\
South Buenos Aires Province, Argentina & \\
$\left(38^{\circ} 08^{\prime} \mathrm{S}\right.$ - $\left.40^{\circ} 30^{\prime} \mathrm{S}\right)$ & $0.0734^{3}$ \\
\hline \hline
\end{tabular}

(1) Di Beneditto and Ramos (2001); (2) present study;(3) Ott et al. (2002). 
This hypothesis was considered by Secchi and Ott (2000) to explain the differences in the fishing effort and CPUE of the franciscana along Rio Grande do Sul State coast $\left(\sim 29^{\circ}-32^{\circ} \mathrm{S}\right)$, southern Brazil. The authors suggested that as the $30-\mathrm{m}$ isobath is close to shore, the area available for franciscanas is limited, which in turn would result in the observed large densities and, consequently, higher by-catch rates.

The data on marine tucuxi by-catch in northern Rio de Janeiro indicate the $30-\mathrm{m}$ isobath as its offshore limit and the occurrence of the species beyond this depth has never been recorded along its known range. I suspect that the inshore distribution of its preferred prey and the presence of potential competitors and predators might influence its distribution pattern in deeper waters.

The by-catch data on franciscanas, on the other hand, indicate that they might occur more commonly in the first 5-7n.miles from shore in Areas I and II, where the depths are 7-15m and 15-30m, respectively. During 1993 98, sightings of franciscanas in northern Rio de Janeiro were recorded in Di Beneditto et al. $(2001 b)$ and the observation effort included waters $\leq 60 \mathrm{~m}$ deep. More than $90 \%$ of these sightings were obtained up to 5 n.miles and up to $15 \mathrm{~m}$ of depth. Siciliano et al. (2002) analysed the same dataset through geo-reference and verified that sightings of franciscana in Area I were strongly correlated to river runoffs.

Studies on franciscana feeding habits in northern Rio de Janeiro indicated that their diet was composed of juvenile squid and and croakers (sciaenids), in addition to anchovies (engraulids) and sardines (clupeids), mostly associated with estuaries and coastal areas near river mouths (Di Beneditto and Ramos, 2001). The occurrence and/or density of its preferred prey species may limit its distribution, especially in north São Tomé Cape region (Area I), as was also reported by Siciliano et al. (2002).

The by-catch data of the franciscana and the marine tucuxi showed that their distribution in northern Rio de Janeiro may be constricted by the bathymetric characteristics of the area. Human activities, such as gillnet fisheries, can cause serious impact on their populations, particularly if they are of small size. As such, gillnet fisheries should not operate within 10n.miles from shore between São Tomé Cape $\left(22^{\circ} 00^{\prime} \mathrm{S}\right)$ and Macaé $\left(22^{\circ} 25^{\prime} \mathrm{S}\right)$, as the $30-\mathrm{m}$ isobath can be found very close to shore. In addition, fisheries operating near the Paraíba do Sul river mouth could adversely impact franciscanas, and pose a threat for the conservation of the species in the area.

\section{Acknowledgements}

I thank Ignácio Moreno, Enrique Crespo, Eduardo Secchi and Nélio Barros for the review on this manuscript; Leandro Monteiro for helping in the statistics analysis; fishermen from Atafona village for information about fisheries and small cetaceans captures and Silvana Gomes for helping in the field activities. The author was supported by Conselho Nacional de Desenvolvimento Científico e Tecnológico - CNPq (Process no. 470157/ 01-1), Fundação Estadual Norte Fluminense - FENORTE and Parque de Alta Tecnologia - TECNORTE. Research Permit was provided by Instituto Brasileiro do Meio Ambiente e dos Recursos Naturais Renováveis - IBAMA (Permit no. 012-02/CMA/IBAMA).

\section{References}

Carlson, J.K. and Cortés, E. (2003) Gillnet selectivity of small coastal sharks off the southeastern United States. Fisheries Research, 60(2-3): 405-415.

Corcuera, J. (1994) Incidental mortality of franciscanas in Argentine waters: the threat of small fishing camps. Report of the International Whaling Commission, 15: 291-294.

Corcuera, J., Monzon, F., Crespo, E.A., Aguilar, A. and Raga, J.A. (1994) Interactions between marine mammals and the coastal fisheries of Necochea and Claromecó (Buenos Aires Province, Argentina). Report of the International Whaling Commission, 15: 283-290.

Di Beneditto, A.P. (1997) Captura acidental de pequenos cetáceos em rede de espera: uma ameaça às populações do Norte do Rio de Janeiro? Thesis. Universidade Estadual do Norte Fluminense. Campos dos Goytacazes, Brazil. 91p.

Di Beneditto, A.P.; Ramos, R. and Lima, N.R.W. (1998) Fishing activity on Northern Rio de Janeiro State (Brazil) and its relation with small cetaceans. Brazilian Archives of Biology and Technology, 41(3): 296-302.

Di Beneditto, A.P. (2001) A pesca artesanal na costa norte do Rio de Janeiro. Bioikos, 15(2): 103-107.

Di Beneditto, A.P. and Ramos, R. (2001) Biology and conservation of the franciscana (Pontoporia blainvillei) in the north of Rio de Janeiro, Brazil. Journal of Cetacean Research and Management, 2(3): 185-192.

Di Beneditto, A.P.; Ramos, R. and Lima, N.R.W. (2001a) Os golfinhos: origem, classificação, captura acidental, hábito alimentar. Editora Cinco Continentes, Porto Alegre, Brazil. 152p.

Di Beneditto, A.P.; Ramos, R. and Lima, N.R.W. (2001b) Sightings of Pontoporia blainvillei (Gervais \& D'Orbigny, 1844) and Sotalia fluviatilis (Gervais, 1853) (Cetacea) in South-eastern Brazil. Brazilian Archives of Biology and Technology, 44(3): 291-296.

Garcia-Mellado, A., Oliva-Paterna, F.J., Carvalho, E.D. and Torralva, M. (2002) Catch and selectivity parameters of the anastomid fish Schizodon nasutus using gillnets in the Jurumirim reservoir (São Paulo, Brazil). Italian Journal of Zoology, 69(4): 333-338.

Lodi, L. and Capistrano, L. (1990) Capturas acidentais de pequenos cetáceos no litoral norte do Rio de Janeiro. Biotemas, 3: 47-65.

Martin, L., Dominguez, J.L. and Bittencourt, A.C.P. (1998) Climatic control of coastal erosion during a sea-level fall episode. Anais da Academia Brasileira de Ciências, 70(2): 249-266.

Monteiro Neto, C.; Alves Júnior, T.; Ávila, F.C.; Campos, A.; Costa, A.F.; Silva, C.N. and Furtado-Neto, M.A. (2000) Impact of fisheries on the tucuxi (Sotalia fluviatilis) and rough-toothed dolphin (Steno bredanensis) populations off Ceará state, northeastern Brazil. Aquatic Mammals, 26(1): 49-56.

Muehe, D. and Valentini, E. (1998) O litoral do Estado do Rio de Janeiro: uma caracterização físico-ambiental. Ed. FEMAR, Rio de Janeiro, Brazil. 99p. 
Norse, E.A. (1993) Global marine biological diversity: a strategy for building conservation into decision making. Island Press, Washington, USA. 383p.

Ott, P.H. (1998) Análise das capturas acidentais de Pontoporia blainvillei (Gervais \& D'Orbigny, 1844) (Cetacea, Pontoporiidae) nas comunidades pesqueiras do litoral norte do Rio Grande do Sul, sul do Brasil. Thesis. Pontifícia Universidade Católica do Rio Grande do Sul. Porto Alegre, Brazil. 121p.

Ott, P.H., Secchi, E.R., Moreno, I.B., Danilewicz, D., Crespo, E.A, Bordino, P., Ramos, R., Di Beneditto, AP., Bertozzi, C., Bastida, R., Zanelatto, R.C., Perez, J.E. and Kinas, P.G. (2002) Report of the working group on fishery interactions. The Latin American Journal of Aquatic Mammals, 1(1): 55-64.

Perez-Macri, G. and Crespo, E.A. (1989) Survey of the franciscana, Pontoporia blainvillei, along the argentine coast, with a preliminary evaluation of mortality in coastal fisheries in Biology and conservation of river dolphins, Occasional Papers of the IUCN, SSC, 3: 57-63.

Praderi, R. (1997) Análisis comparativo de estadísticas de captura y mortalidad incidental de Pontoporia blainvillei em Uruguay durante 20 años. Pages 42-53 in Anais do $2^{\circ}$ Encontro sobre Coordenação de Pesquisa e Manejo da Franciscana. Ed. FURG, Rio Grande, Brazil.

Praderi, R., Pinedo, M.C. and Crespo, E.A. (1989) Conservation and Management of Pontoporia blainvillei in Uruguay, Brazil and Argentina in Biology and conservation of river dolphins, Occasional Papers of the IUCN, SSC, 3: 52-55.

Secchi, E.R., Zerbini, A.N., Bassoi, M., Dalla Rosa, L., Möller, L.M. and Rocha-Campos, C. (1997) Mortality of franciscanas, Pontoporia blainvillei, in coastal gillnets in
Southern Brazil: 1994-1995. Report of the International Whaling Commission, 47: 653-658.

Secchi, E.R.,Wang, J.Y., Murray, B., Rocha-Campos, C. and White, B.N. (1998) Population differentiation in the franciscana (Pontoporia blainvillei) from two geographic locations in Brazil as determined from mitochondrial DNA control region sequences. Canadian Journal of Zoology, 76: 1622-1627.

Secchi, E.R. and Ott, P.H. (2000) A profundidade como um fator determinante da distribuição de densidade de toninhas, Pontoporia blainvillei, conforme indicado pelos índices de CPUE. Pages 55-57 in UNEP/CMS (Eds) Report of the Third Workshop for Coordinated Research and Conservation of the Franciscana Dolphin (Pontoporia blainvillei) in the Southwestern Atlantic. UNEP/CMS, Bonn, Germany.

Siciliano, S. (1994) Review of small cetacean and fishery interactions in coastal waters of Brazil. Report of the International Whaling Commission, 15: 653-658.

Siciliano, S., Di Beneditto, A.P. and Ramos, R. (2002) A toninha, Pontoporia blainvillei (Gervais \& d'Orbigny, 1844) (Mammalia, Cetacea, Pontoporiidae), nos Estados do Rio de Janeiro e Espírito Santo, costa sudeste do Brasil: caracterização dos hábitats e possíveis fatores de isolamento das populações. Boletim do Museu Nacional, Nova Série, Zoologia, 146: 1-15.

Valentin, J.L. and Monteiro-Ribas, W.M. (1993) Zooplankton community structure on the East-southeast Brazilian continental shelf $\left(18^{\circ}-23^{\circ} \mathrm{S}\right)$. Continental Shelf Research, 13(4): 407-424.

Zar, J.H. (1996) Biostatistical analysis. Prentice Hall, New Jersey, USA. 662 p. 